\title{
Influence of Mullite Wool Waste on the Properties of Ceramics
}

\author{
Jurgita MALAIŠKIENE் * \\ Department of Building Materials, Vilnius Gediminas Technical University, \\ Sauletekio av. 11, LT-10223 Vilnius, Lithuania
}

Received 04 November 2010; accepted 10 January 2011

\begin{abstract}
In the paper, the influence of mullite wool waste additive on the properties of building ceramics is analysed. For that purpose four formation masses were prepared, dried and fired at the analogous regimes (maximum firing temperature $1080^{\circ} \mathrm{C}$ ). The fired samples were used to determine the structural and physical-mechanical properties. The values of these parameters are analysed: water absorption, total and effective porosity, rate of capillary mass flow, reserve of porous volume, compressive strength, density and estimated exploitation frost resistance. It has been determined that mullite wool waste can be applied to the production of building ceramics and the optimum quantity of waste in a formation mass is $10 \%$ according to weight. Water absorption of those ceramic samples was less than $4 \%$, compressive strength was $28.6 \mathrm{MPa}$, density $-2033 \mathrm{~kg} / \mathrm{m}^{3}$, forecasted resistance to frost about 400 cycles.

Keywords: mullite wool, building ceramics, structural, physical, mechanical properties.
\end{abstract}

\section{INTRODUCTION}

In the modern manufacture of building materials the technogenic waste is utilized more and more frequently. In this way ecological problems are being solved, companies save costs of waste removal and storage, even the properties of ceramic articles are often improved. Therefore many scientists work in this field of research.

The scientists [1-3] have analysed the model system of easily fusible illite clay and fibre mineral wool waste; they have determined that mineral wool waste can be used in the production of sintered ceramic articles. Replacing $20 \%$ of sand with the mineral wool waste, keeping $80 \%$ of easily fusible illite clay in a formation mass and firing the shaped samples at $1040{ }^{\circ} \mathrm{C}$ maximum temperature, the sintered ceramics with water absorption $2.02 \%$ and $2169 \mathrm{~kg} / \mathrm{m}^{3}$ density have been produced.

The waste of ground glass is often applied in scientific investigations. The scientists [4] have analysed the influence of three waste glasses on the properties of ceramic samples. Using these wastes, the sintering temperature was decreased from $1100{ }^{\circ} \mathrm{C}$ to $950{ }^{\circ} \mathrm{C}$. The other researchers [5] have used SiC-based waste from polishing glass articles. It has been determined, that with the waste quantities of 5, 10 and $15 \%$ the ceramics both with low density and with especially large porosity can be produced. The scientists [6-7] have investigated the influence of several types of glass waste, lime and mining residues on the properties of ceramics. It has been determined that applying these wastes and firing the samples at the relatively low temperature $\left(880^{\circ} \mathrm{C}-930^{\circ} \mathrm{C}\right)$ for $1-3 \mathrm{~h}$, it is possible to produce the ceramic articles with compressive strength of $100 \mathrm{MPa}$, and density of $2600 \mathrm{~kg} / \mathrm{m}^{3}$.

The authors of the publication [8] have used the recycled paper processing residues, containing $\mathrm{CaO}$ $(32.9 \%)$ and cellulose fibres $(53.8 \%)$.

The investigation showed that depending on the firing temperature and the quantity of waste in a formation mass

\footnotetext{
*Corresponding author. Tel.: +370-5-2745219; fax.: +370-5-2745016. E-mail address: jurgita.malaiskiene@vgtu.lt (J. Malaiškienė)
}

$(20,30,40$ or $50 \%)$, density of samples ranged from $1290 \mathrm{~kg} / \mathrm{m}^{3}$ to $1940 \mathrm{~kg} / \mathrm{m}^{3}$, and compressive strength from $8 \mathrm{MPa}$ to $43 \mathrm{MPa}$.

The scientists [9] have analysed the effective use of several wastes in the production of building materials (Al-rich anodising sludge, sludge from the filtration or clarification of potable water, sludge generated in marble sawing processes and foundry sand). Performing examinations of chemical and mineralogical composition, DTA analysis, they have concluded that these wastes can be applied in the manufacturing of fire resistant and cement materials.

Another waste material often applied in the investigations of ceramic samples is fly ash. The researchers [10] have applied 20,40,60 and $80 \%$ of this waste to the formation masses. The results showed that the additive of fly ash decreases bending strength and increases water absorption of ceramic tiles, however all produced ceramic tiles satisfied the B III of ISO 13006 (1998) requirements. The scientists [11] have applied additives of fly ash, waste glass and silica fume and have obtained samples with the following characteristics: strength $300 \mathrm{MPa}$, density $2.9 \mathrm{~g} / \mathrm{cm}^{3}$, water absorption less than $6 \%$. The authors of publication [12] have determined that adding lime to fly ash, crystal structures form at much lower temperature. The paper [13] states that applying $10 \%$ of coal fly ash from thermal power station to formation mass the obtained ceramics is non-hazardous and has good chemical resistance and mechanical properties. The researchers [14] explain that it is possible to produce glass-ceramic and ceramic materials from fly ash without any additives and they have several properties, which would make them attractive to industrial use in construction and tiling.

The scientists [15] have determined that the additions of chamotte particles $(10,20$ and $30 \mathrm{wt} . \%)$ to the starting composition (formulated from fly ash, peat ash and clay) resulted in a material with relatively high ultimate strength, $72 \mathrm{MPa}$. The chamotte additives have increased the sintering interval from $20^{\circ} \mathrm{C}$ for the starting composition 
to $40{ }^{\circ} \mathrm{C}$ for the composition with $20 \%$ of chamotte additive.

In the publication [16] it has been discussed that cordierite has been successfully synthesized by using standard raw materials including talc, fly ash, fused silica and alumina. Cordierite has also been found in the composition of one of the raw materials (chamotte) used in our research.

The scientists [17] have used kaolin and granite sawing wastes, the investigation results have been processed by the mathematical methods of statistics. The model has been developed enabling to select the composition of formation mass according to the obtained water absorption and strength. By the developed model it is possible to estimate the above-mentioned properties of samples, to evaluate the influence of each component of formation mass on these properties.

The purpose of this work was to determine the influence of the technogenic raw material on the properties of building ceramics. The technogenic raw material was the thermal insulation waste from production of thermal equipment; the waste material can be called mullite wool

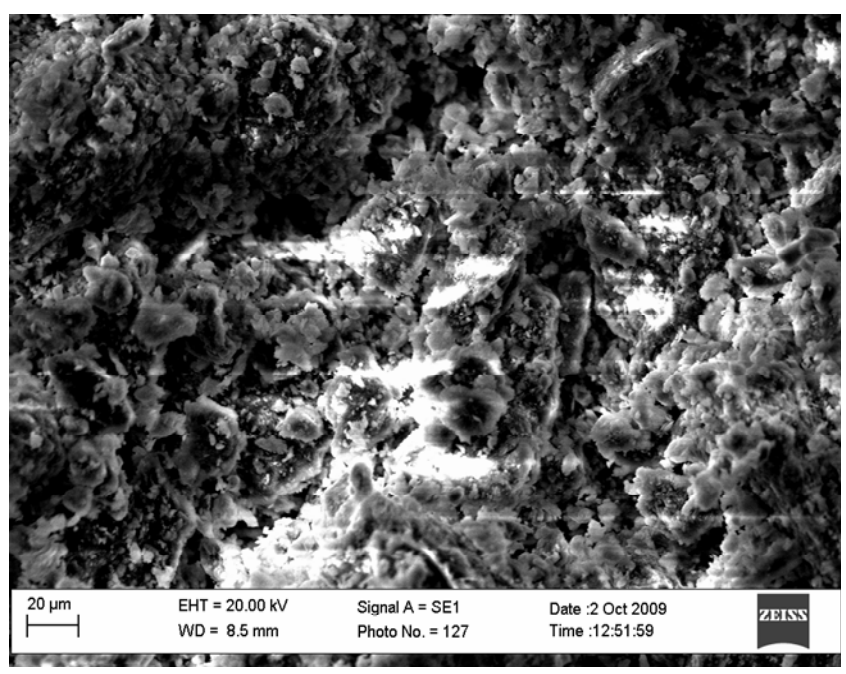

a

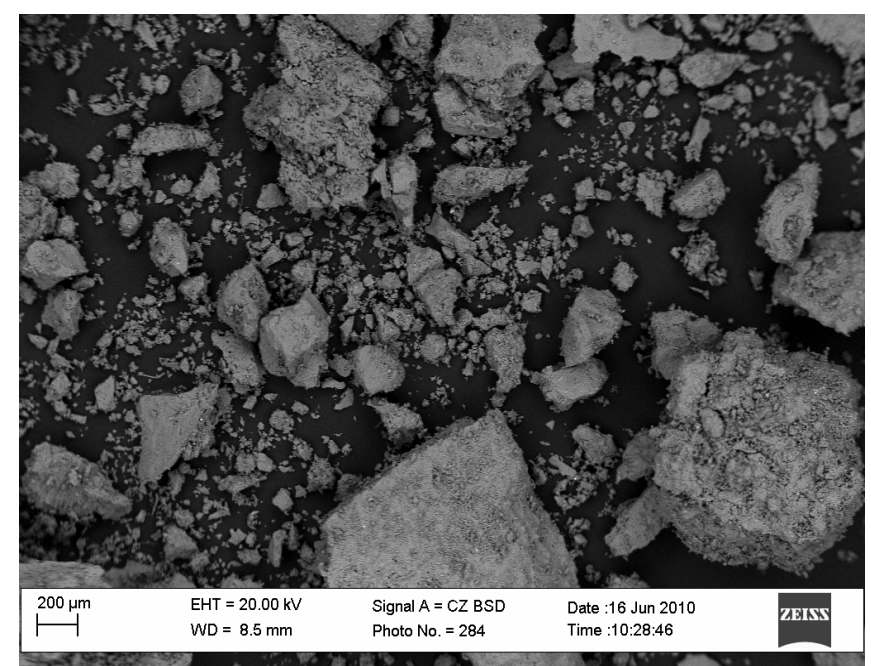

c due to its mineralogical composition. The author was not successful to find any research based on the application of this raw material.

\section{CHARACTERISTICS OF MATERIALS, RESEARCH METHODS}

The ceramic samples with dimensions $(70 \times 70 \times 70) \mathrm{mm}$ were shaped manually. Compositions of the formation masses according to weight are shown in Table 1.

Table 1. Composition of the formation mixes

\begin{tabular}{|c|c|c|c|c|}
\hline $\begin{array}{c}\text { Forma- } \\
\text { tion mix }\end{array}$ & $\begin{array}{c}\text { Quantity } \\
\text { of clay, \% }\end{array}$ & $\begin{array}{c}\text { Quantity } \\
\text { of sand, \% }\end{array}$ & $\begin{array}{c}\text { Quantity of } \\
\text { chamotte, \% }\end{array}$ & $\begin{array}{c}\text { Quantity of } \\
\text { fired mullite } \\
\text { wool waste, \% }\end{array}$ \\
\hline 1 & 80 & 15 & 5 & 0 \\
\hline 2 & 80 & 0 & 5 & 15 \\
\hline 3 & 80 & 5 & 5 & 10 \\
\hline 4 & 80 & 10 & 5 & 5 \\
\hline
\end{tabular}

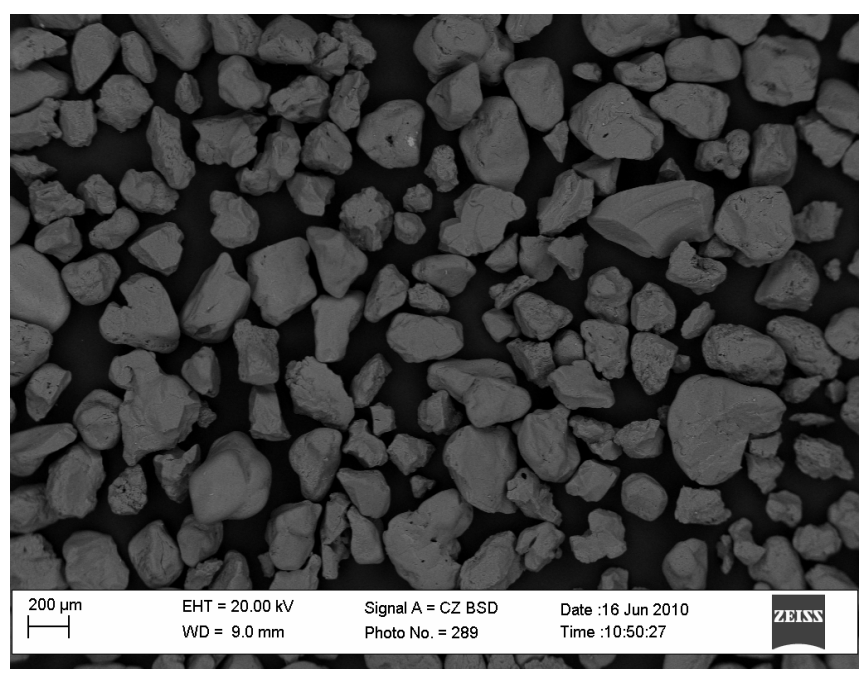

b

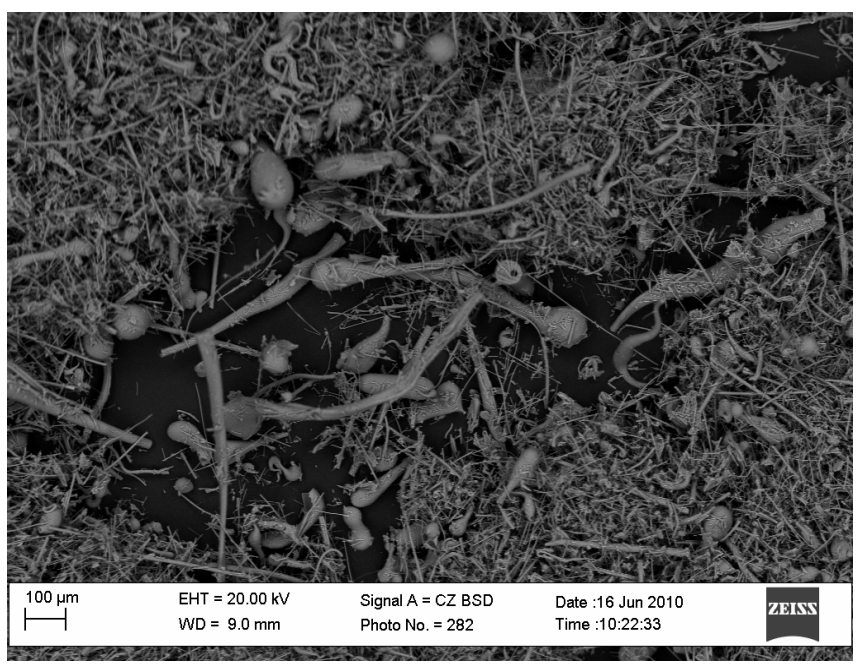

d

Fig. 1. Scanning electron microscopy images of microstructure of used raw materials: $a-$ clay, $b-$ sand, $c-c h a m o t t e, d-$ mullite wool technogenic waste 
Table 2. Granulometric composition of clay from Dysna deposit

\begin{tabular}{|c|c|c|c|}
\hline Deposit & $\begin{array}{c}\text { Amount of sandy fraction (particles } \\
\text { larger than } 0.05 \mathrm{~mm}), \%\end{array}$ & $\begin{array}{c}\text { Amount of dusty fraction (particles range } \\
\text { from } 0.05 \text { to } 0.005 \mathrm{~mm} \text { ) } \%\end{array}$ & $\begin{array}{c}\text { Amount of clayey fraction } \\
\text { (particles larger than } 0.005 \mathrm{~mm} \text { ), } \%\end{array}$ \\
\hline Dysna & 1.76 & 16.34 & 81.90 \\
\hline
\end{tabular}

Table 3. Average chemical composition of clay from Dysna deposit, $\%$

\begin{tabular}{|c|c|c|c|c|c|c|c|c|}
\hline Deposit & $\mathrm{SiO}_{2}$ & $\mathrm{Al}_{2} \mathrm{O}_{3}+\mathrm{TiO}_{2}$ & $\mathrm{Fe}_{2} \mathrm{O}_{3}$ & $\mathrm{CaO}$ & $\mathrm{MgO}$ & $\mathrm{K}_{2} \mathrm{O}$ & $\mathrm{Na}_{2} \mathrm{O}$ & Loss on ignition \\
\hline Dysna & 51.63 & 20.09 & 7.56 & 5.45 & 1.46 & 3.35 & 1.15 & 9.1 \\
\hline
\end{tabular}

As shown in Fig. 1, the finest parts are in clay (it was passed through $0.63 \mathrm{~mm}$ sieve). The size of particles in all raw materials is different. The biggest difference is seen among the sizes of chamotte particles (it was passed through $0.63 \mathrm{~mm}$ sieve) and mullite wool waste (particles up to $1 \mathrm{~mm}$ ). The particles of the first three raw materials have irregular, rough surface, therefore they intercohere well. The components of the formation mass were chosen to be fining dispersive, in order to accelerate the sintering processes.

From Fig. 1 it was hard to decide on the surface roughness of mullite wool waste, therefore additional microstructural analysis has been performed to obtain the image and the size of mullite wool fibres (Fig. 2).

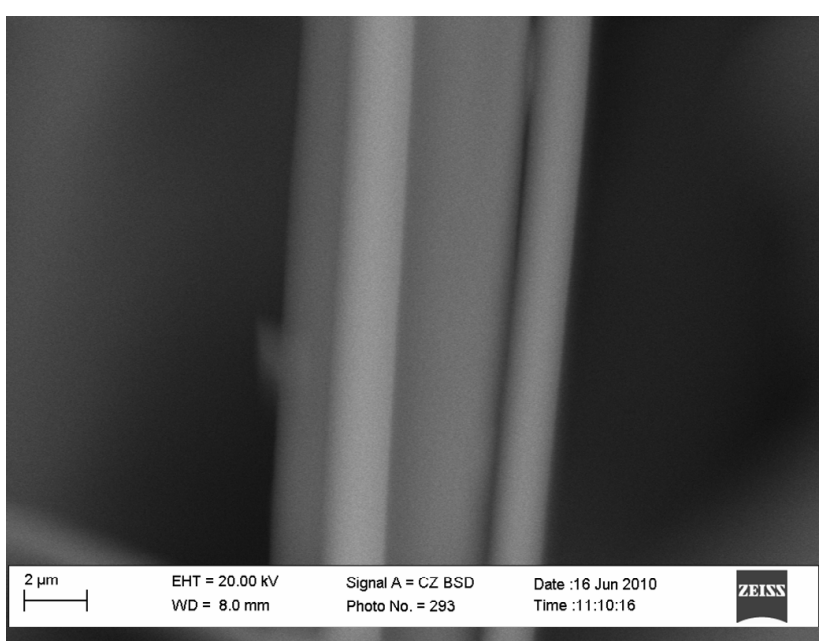

Fig. 2. Scanning electron microscopy image of mullite wool waste fibres

As shown in Fig. 2, the length (about $0.5 \mathrm{~mm}-1 \mathrm{~mm}$ ) and the diameter (from $1 \mu \mathrm{m}$ to $25 \mu \mathrm{m}$ ) of fibres are very different; however the surface of fibres is smooth.

Granulometric composition of the main raw material clay - has been determined according to LST EN 725-5 and is presented in Table 2. Chemical composition of clay is presented in Table 3 [18]. The microstructural analysis of the raw materials and samples has been performed with the scanning electron microscope Carl Zeis Evo LS 25 [19]. The pictures of microstructure of all raw materials are shown in Fig. 1.

The samples made of the analysed raw materials were dried to the constant mass; their firing regime is shown in Fig. 3. The sintered and cooled samples were used to determine the physical-mechanical and structural parameters.

The density and water absorption of the ceramic samples were being set using standard LST EN 771-1+A1. Compressive strength of the ceramic samples was being set according to LST EN 772-1. The exploitation frost resistance forecasted according to the methodology of parameters of structure [20-21] calibrated according to LST 1413.12:1998.

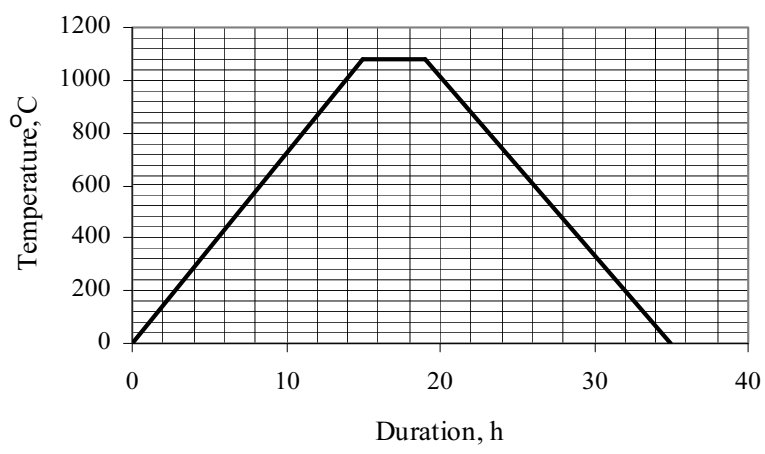

Fig. 3. Firing regime of the ceramic samples

\section{RESEARCH RESULTS AND ANALYSIS}

The results of water absorption are presented in Fig. 4. It can be seen in Fig. 4, that the water absorption for all batches, determined after $72 \mathrm{~h}$, is less than $4 \%$. The largest water absorption is observed for the samples with $15 \%$ of the thermal insulation waste, used in production of thermal equipment. The water absorption for the other batches, determined after $72 \mathrm{~h}$, is almost constant.

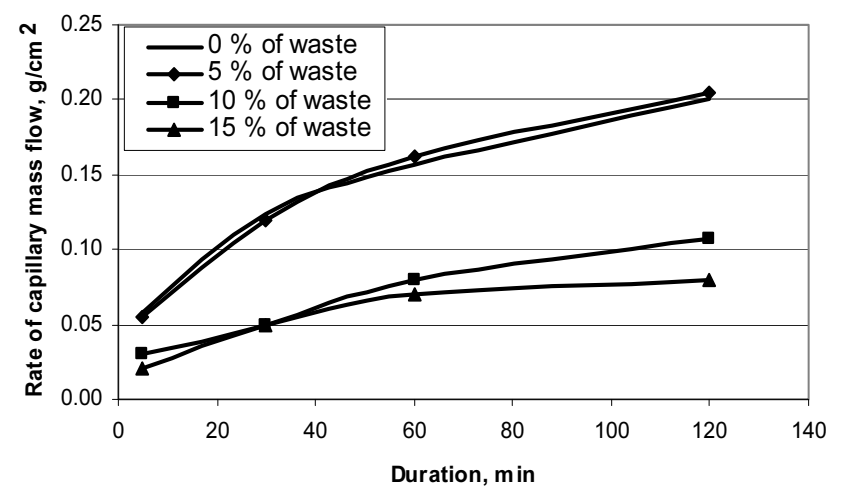

Fig. 4. Change in water absorption by soaking time of ceramic samples with different waste content

However, for these batches, the diverse rate of water absorption is noticed for the first $20 \mathrm{~min}$ of contact with water. Samples with $10 \%$ of waste material absorb water slowlier, while samples without waste reach almost the same water absorption in $5 \mathrm{~min}$ as after $72 \mathrm{~h}$.

Fig. 5 shows that (as expected) the samples without waste and the samples having $5 \%$ of waste additive have 
almost the same rate of capillary mass flow, which is bigger than the one for the samples with $10 \%$ and $15 \%$ waste.

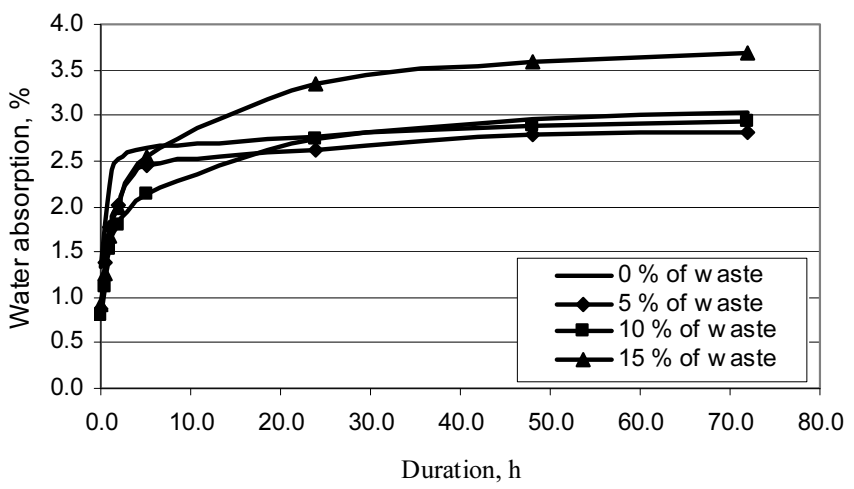

Fig. 5. Alteration of capillary mass flow rate, depending on the duration of contact with water and the quantity of waste in the formation mass

This effect can be explained by the larger diameter of pores and capillaries [20-21], which can be defined by determining the values of capillary mass flow rate (Fig. 5).

The ceramic samples with $10 \%$ and $15 \%$ of thermal insulation waste material received quite small and almost
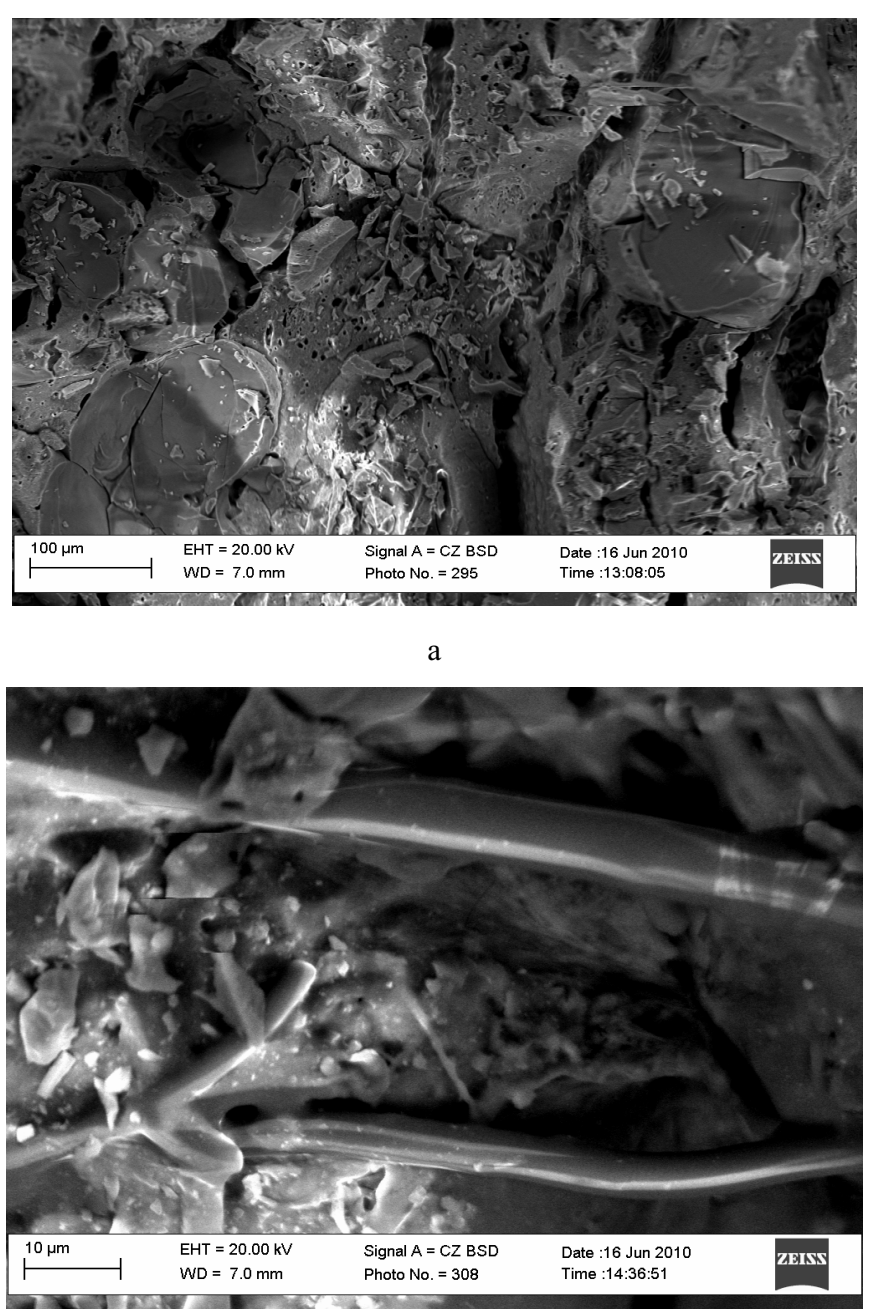

the same value after $30 \mathrm{~min}-0.05 \mathrm{~g} / \mathrm{cm}^{2}$. According to the research results, it can be stated that the samples containing $10 \%$ and $15 \%$ of waste have pores and capillaries with the smaller relative diameter, therefore they absorb water slowlier. This is also illustrated in the microstructure of samples (Fig. 6).

The size of pores and capillaries in the samples without waste material is $60 \mu \mathrm{m}$ (Fig. 6, a) and in the samples with $10 \%$ of thermal insulation material waste (Fig. 6, b) - approximately $20 \mu \mathrm{m}-30 \mu \mathrm{m}$. As seen in Fig. 6, c, and 6, d, the mullite wool is a fibrous additive, which gives stiffness to material and should increase compressive strength. However, the fibres of mullite wool have too even surface, which decreases coherence with other materials; and bigger quantity of the fibres might decrease the strength.

Later the other structural parameters were determined [20].

The results of effective and total open porosity are presented in Fig 7.

Effective porosity of ceramic body defines the amount of effectively working pores and capillaries. Total open porosity defines the total open porous space of ceramic body in macrostructure and microstructure dimension. Following characteristics were determined according to [20].

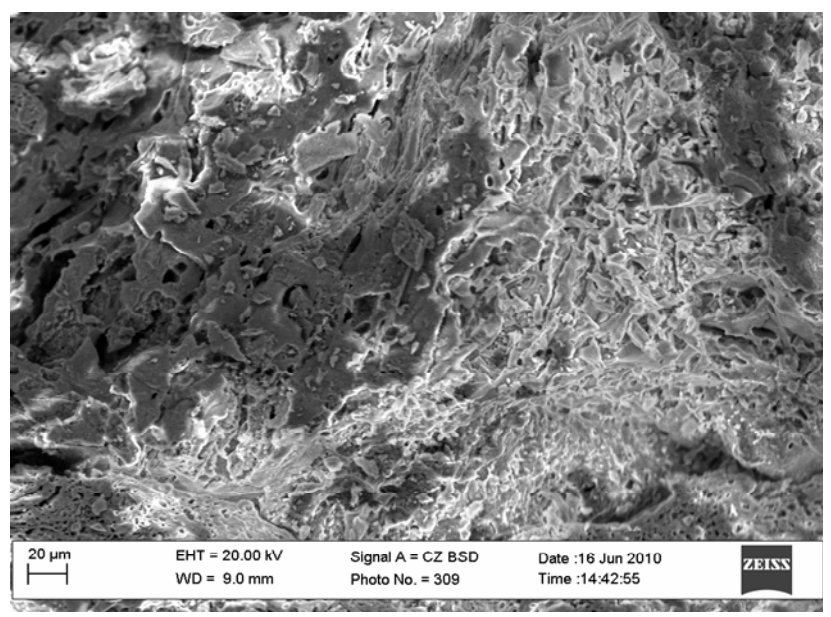

b

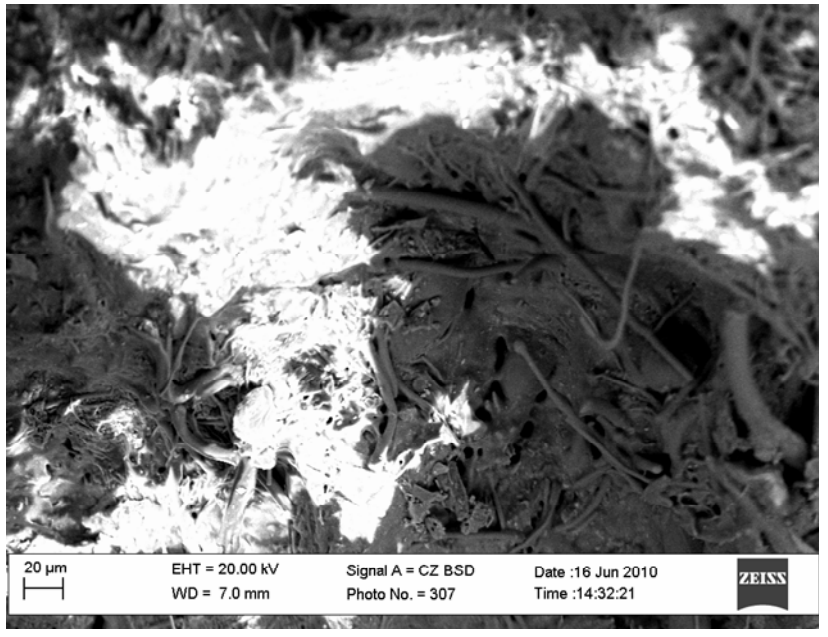

d

Fig. 6. Scanning electron microscopy images of microstructure of samples (a) without waste material and (b, c, d) with $10 \%$ waste 
Table 4. Physical-mechanical and structural parameters of ceramic samples

\begin{tabular}{|c|c|c|c|c|c|c|c|c|}
\hline $\begin{array}{c}\text { Formation } \\
\text { mix }\end{array}$ & $\begin{array}{c}R_{g n}, \\
\mathrm{MPa}\end{array}$ & $\begin{array}{c}\rho, \\
\mathrm{kg} / \mathrm{m}^{3}\end{array}$ & $\begin{array}{c}R_{p}, \\
\%\end{array}$ & $\begin{array}{c}D, \\
\%\end{array}$ & $\begin{array}{c}G_{1}, \\
\mathrm{~g} / \mathrm{cm}^{2}\end{array}$ & $\begin{array}{c}G_{2}, \\
\mathrm{~g} / \mathrm{cm}^{2}\end{array}$ & $\begin{array}{c}N, \\
\mathrm{units}\end{array}$ & $\begin{array}{c}g, \\
\mathrm{~g} / \mathrm{cm}^{2}\end{array}$ \\
\hline 1 & 17.7 & 2050 & 60.86 & 5.18 & 0.207 & 0.185 & 0.916 & 0.123 \\
\hline 2 & 25.8 & 1915 & 54.64 & 5.04 & 0.138 & 0.175 & 0.853 & 0.049 \\
\hline 3 & 28.6 & 2033 & 60.2 & 5.44 & 0.157 & 0.159 & 0.555 & 0.054 \\
\hline 4 & 16.4 & 2035 & 63.56 & 5.07 & 0.232 & 0.181 & 1.2 & 0.119 \\
\hline
\end{tabular}

Explanation: $R_{g n}$ - compressive strength, $\rho$ - density, $R_{p}$ - reserve of porous volume, $D$ - relative wall thickness of pores and capillaries, $G_{1}$ - rate of capillary mass flow in vacuum in the direction of freezing, $G_{2}$ - rate of capillary mass flow in vacuum in the direction perpendicular to freezing, $N$ - degree of structural inhomogeneity, $\mathrm{g}$ - rate of capillary mass flow in normal conditions.

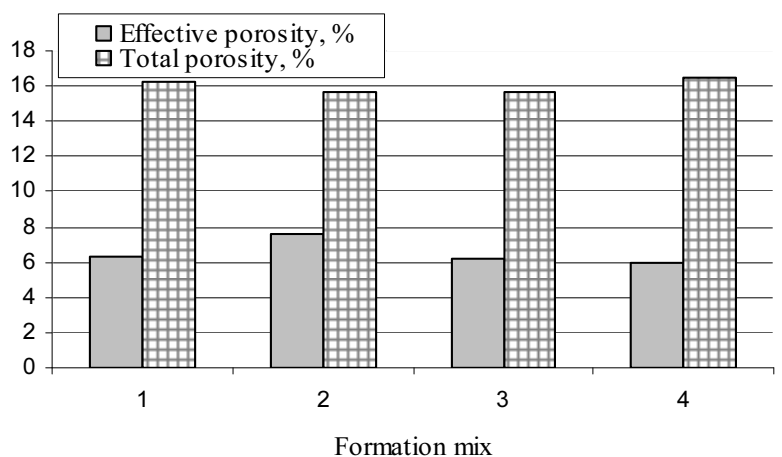

Fig. 7. Values of effective and total open porosity

It can be seen in Fig. 7, that effective porosity of all samples is less than $26 \%$; according to it the estimating equations of exploitation frost resistance are selected $[20-21]$. The used waste material affects the values of total porosity only slightly, as this parameter for all batches is almost the same. The slight difference of effective porosity is seen only in the samples containing $15 \%$ of mullite wool waste.

The physical and structural parameters of samples determined according to the compositions of formation masses are presented in Table 4.

According to the results shown in Table 4, it can be defined that the thermal insulation material waste, used in the production of thermal equipment, decreases density of ceramic body, its structural inhomogeneity and rate of capillary mass flow, but increases compressive strength. Adding more than $10 \%$ of the waste material to the formation mass, the reserve of porous volume decreases, more merging pores and capillaries form, what is not beneficial from the point of view of exploitation frost resistance, the compressive strength starts to decrease as well.

The estimated exploitation frost resistance has been calculated according to the experiment data are provided in Table 4 [20-21].

Fig. 8 shows the average values of forecasted frost resistance according to the quantity of waste in a formation mass. The exploitation frost resistance was calculated for the beginning and the end of the breakup; afterwards the average value of these parameters has been derived.

From Fig. 8, it can be concluded that the thermal insulation material waste, used in the production of thermal equipment, increased the exploitation frost resistance almost by $50 \%$. The biggest estimated frost resistance has been obtained adding $10 \%$ of the mullite wool to the formation mass.

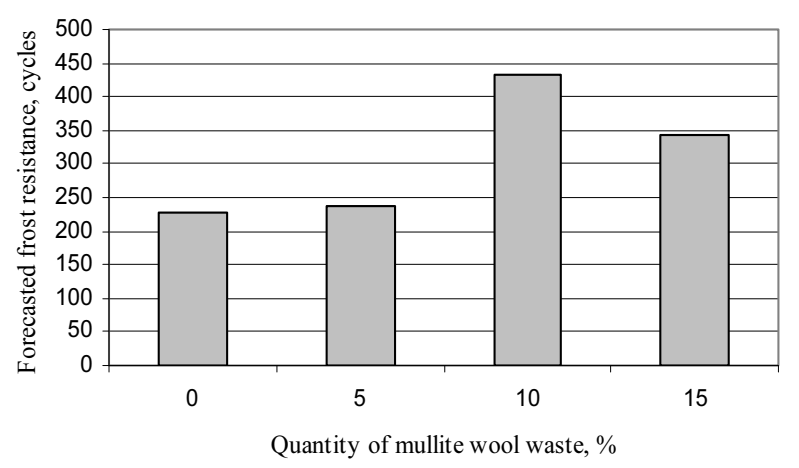

Fig. 8. Average exploitation frost resistance against the quantity of mullite wool waste in the formation mass

As shown by other researchers various wastes could be used in the manufactory of building ceramics. Generally the optimum quantity of waste in formation mix is about $10 \%$ [22-24]. Different wastes could improve some properties of products (strength, frost resistance and others). It can be seen from this work, that mullite wool waste could increase the frost resistance, compressive strength and decrease density of building ceramics.

\section{CONCLUSIONS}

- It has been determined that the samples with mullite wool (thermal insulation material waste, used in the manufacture of thermal equipment) have pores and capillaries with more than $50 \%$ smaller diameter.

- The water absorption (determined adding up to $10 \%$ of the mullite wool waste to the formation mass) is almost constant. However the kinetics of water absorption is very different for the first minutes. The samples without the waste additive absorb water and settle most rapidly, the ones with $10 \%$ of the waste additive absorb water slowlier, but after three days the values of water absorption are almost equal. The water absorption for all batches is less than $4 \%$, therefore sintered ceramics may be produced using the additive of mullite wool waste up to $15 \%$ in a formation mass.

- The rate of capillary mass flow in the batches without waste and in the ones with $5 \%$ of mullite wool waste has been received almost the same, however it is about $55 \%$ bigger than in the batches with $10 \%$ and $15 \%$ of waste (the values of capillary mass flow rate in these batches differ only slightly).

- $\quad$ The estimated average frost resistance varied from 220 cycles (in the samples without waste additive) to 440 
cycles (when $10 \%$ of the mullite wool waste has been applied to the standard formation mass). The mullite wool waste is decreasing the density of a ceramic body, its structural inhomogeneity and the rate of capillary mass flow and it increases significantly the compressive strength. It has been determined, that putting $15 \%$ of the waste to a formation mass, the reserve of porous volume decreases.

- Performing research, it has been determined that the mullite wool waste can be successfully applied for the manufacture of sintered ceramics. Taking into account the frost resistance and the compressive strength, the optimum quantity of the waste in the formation mass is $10 \%$.

\section{Acknowledgements}

The author is grateful for the support of this work by the Forensic Science Centre of Lithuania Gabriele Juodkaitè-Granskienè, Vytautas Jonaitis and Jonas Mincevičius.

\section{REFERENCES}

1. Balkevičius, V., Pranckevičienė, J. Investigation of Properties of Composite Ceramics Materials Science (Medžiagotyra) 14 (1) 2008: pp. 55-58.

2. Pranckevičienè, J., Balkevičius, $\mathbf{V}$. Investigation into the Properties of Sintered Ceramics from Dysna Clay and NonPlastics Additives Civil Engineering (Statyba) 1 (5) 2009: pp. 15-19 (in Lithuanian).

3. Balkevičius, V., Christauskas, J., Gailius, A., Špokauskas, A., Siaurys, V. Analysis of Some Properties of Model System From Low-Melting Illite Clay and Fibrous Mineral Wool Waste Materials Science: an Interdisciplinary Journal of Physics, Chemistry and Technology of Materials 25 (1) 2007: pp. 209-217.

4. Bernardo, E., Bonomo, E., Dattoli, A. Optimisation of Sintered Glass-Ceramics from an Industrial Waste Glass Ceramics International 36 2010: pp. 1675-1680.

5. Bernardo, E. Micro- and Macro-cellular Sintered GlassCeramics from Wastes Journal of the European Ceramic Society 27 2007: pp. 2415-2422.

6. Bernardo, E., Castellan, R., Hreglich, S. Sintered GlassCeramics from Mixtures of Wastes Ceramics International 33 2007: pp. 27-33.

7. Bernardo, E., Castellan, R., Hreglich, S., Lancellotti. Sintered Sanidine Glass-Ceramics from Industrial Wastes Journal of the European Ceramic Society 262006 : pp. $3335-3341$.

8. Sutcu, M., Akkurt, S. Utilization of Recycled Paper Processing Residues and Clay of Different Sources for the Production of Porous Anorthite Ceramic Journal of the European Ceramic Society 30 2010: pp. 1785-1793.

9. Raupp-Pereira, F., Hotza, D., Segadaes, A. M., Labrincha, J. A. Ceramic Formulations Prepared with Industrial Wastes and Natural Sub-Products Ceramics International 32 2006: pp. 173-179.
10. Zimmer, A., Bergmann, C. P. Fly Ash of Mineral Coal as Ceramic Tiles Raw Material Waste Management 27 2007: pp. 59-68.

11. Erol, M., Kucukbayrak, A., Ersoy-Mericboyu, A. The Influence of the Binder on the Properties of Sintered GlassCeramics Produced from Industrial Wastes Ceramics International 35 2009: pp. 2609-2617.

12. Karoly, Z., Mohai, I., Toth, M., Weber, F., Szepvolgyi, J. Production of Glass-Ceramics from Fly Ash Using Arc Plasma Journal of the European Ceramic Society 27 2007: pp. $1721-1725$.

13. Zhang, J., Dong, W., Li, J., Qiao, L., Zheng, J., Sheng, J. Utilization of Coal Fly Ash in the Glass-Ceramic Production Journal of Hazardous Materials 149 2007: pp. 523-526.

14. Erol, M., Kucukbayrak, S., Ersoy-Mericboyu, A. Comparison of the Properties of Glass, Glass-Ceramic and Ceramic Materials Produced from Coal Fly Ash Journal of Hazardous Materials 153 2008: pp. 418-425.

15. Rozenstrauha, I., Bajare, D., Cimdins, R., Berzina, L., Bossert, J., Boccaccini, A. R. The Influence of Various Additions on a Glass-Ceramic Matrix Composition Based on Industrial Waste Ceramics International 32 2006: pp. $115-119$.

16. Goren, R., Ozgur, C., Gocmez, H. The Preparation of Cordierite from Talc, Fly Ash, Fused Silica and Alumina Mixtures Ceramics International 32 2006: pp. 53-56.

17. Menezes, R. R., Malzac Neto, H. G., Santana, L. N. L., Lira, H. L., Ferreira, H. S., Neves, G. A. Optimization of Wastes Content in Ceramic Tiles Using Statistical Design of Mixture Experiments Journal of the European Ceramic Society 28 2008: pp. 3027-3039.

18. Mačiulaitis, R., Žurauskienè, R. Low Porosity Building Ceramics Produced from Local and Technogenic Raw Materials. Vilnius: Technika, 2007, 220 p. (in Lithuanian).

19. Goldstein, J., Newbury, D. E., Joy, D. C., Echlin, P., Lyman, C. E., Lifshin, E. Scaning Electron Microscopy and X-ray Microanalysis. New York : Springer, cop., 2008: $690 \mathrm{p}$.

20. Mačiulaitis, R. Frost Resistance and Durability of Facade Bricks. Frostwiderstand und Dauerhaftigkeit Keramischer Fassadenerzeugnisse. Vilnius: Technika, 1996: 132 p.

21. Kičaitė, A., Malaiškienė, J., Mačiulaitis, R., Kudabienė, G. The Analysis of Structural and Deformational Parameters of Building Ceramics from Dysna Clay In: Proceedings of $10^{\text {th }}$ International Conference "Modern Building Materials, Structures and Techniques" Held on May 19-21, 2010. Vilnius: Technique, 2010: pp. 143-148.

22. Kizinevich, O., Machyulaitis, R., Kizinevich, V., Yakovlev, G. I. Utilization of Technogenic Material from an Oil-processing Company in the Production of Building Ceramics Glass and Ceramics 63 (1-2) 2006: pp. 64-67.

23. Kizinievič, O., Mačiulaitis, R., Kizinievič, V. Use of Rubber Waste in the Ceramic Materials Science (Medžiagotyra) 12 (3) 2006: pp. 237-242.

24. Kizinievič, O., Žurauskienė, R., Špokauskas, A., Mačiulaitis, R. Application of Catalyst Waste to Ceramics Made of Raw Materials Materials Science (Medžiagotyra) 11 (1) 2005: pp. 51-56.

Presented at the National Conference "Materials Engineering'2010" (Kaunas, Lithuania, November 19, 2010) 